\title{
Malign transformasyon
}

\author{
Malignant transformation
}

\author{
Bahtiyar Demiralp, Çağrı Neyişci, Ahmet Burak Bilekli
}

Gülhane Eğitim ve Araştırma Hastanesi, Ortopedi ve Travmatoloji Anabilim Dalı, Ankara

\begin{abstract}
Yüksek enerjili travmayı takiben enfeksiyon gelişimi yumuşak doku problemleri, kemik doku kanlanmasının zayıf olması, hastanın immun yetmezliği ve virulan ve/veya dirençli organizmalar nedeniyle gelişebilir. Bu faktörlerin tümü iyileşmeyi engeller ve potansiyel olarak kronik, tedaviye dirençli bir osteomiyelite yol açabilir. Kronik osteomiyelitin bir sonucu olarak malign transformasyon, modern dünyada azalan bir insidans ile nispeten nadir ve geç görülen bir komplikasyondur. Çoğu hasta için bakteriyel enfeksiyonun ortaya çıkışı ile malign transformasyon arasındaki süre birkaç yıldır. Kronik akıntı yapan bir sinus, malign transformasyon tanısı için yüksek derecede bir klinik şüphe oluşturmalıdır. Özellikle, ağrıda artma, kötü koku ve yara akıntısındaki değişiklikler gibi yeni klinik belirtilerin ortaya çıkması durumlarında biyopsi hemen planlanmalıdır. Kronik osteomiyelit bölgelerinden kaynaklanan malign transformasyonların erken tanı ve agresif yönetimi prognoz ve nihai sonuç için kritik öneme sahiptir. Skuamöz hücreli karsinom en sık görülen malignitedir. Kesin tedavi, tümörün proksimalinden amputasyon veya seçilen hastalarda adjuvan kemoterapi ve radyoterapi ile birlikte geniş eksizyondur. Erken tanı bazen en-blok eksizyon ve ekstremite koruyucu cerrahiye izin verebilir. Bununla birlikte, en etkili tedavi, yeterli debridman, etkilenen bölgenin geniş eksizyonu ve erken rekonstrüksiyon ile osteomiyelitin önlenmesidir.
\end{abstract}

Anahtar sözcükler: osteomiyelit; malign transformasyon; Marjolin ülseri
Infection following high-energy trauma can occur due to soft tissue problems, poor bone tissue vascularization, immune-compromised patient, and virulent and/or resistant organisms. All of these factors compromise healing and can potentially lead to a chronic, treatment-resistant osteomyelitis. Malignant transformation as a result of chronic osteomyelitis is a relatively rare and late complication with a decreasing incidence in the modern world. For most patients, the period between the onset of bacterial infection and malignant transformation is several years. A chronic draining sinus should constitute a high degree of clinical suspicion for the diagnosis of malignant transformation. Biopsy should be planned immediately, especially in cases of new clinical manifestations such as increased pain, bad odor and changes in wound discharge. Early diagnosis and aggressive management of malignant transformation originating from chronic osteomyelitis site is critical for prognosis and the final outcome. Squamous cell carcinoma is the most common malignancy. The definitive treatment is amputation proximal to the tumor or wide excision with adjuvant chemotherapy and radiotherapy in selected patients. Early diagnosis may sometimes allow en bloc excision and limb-sparing surgery. However, the most effective treatment is the prevention of osteomyelitis by adequate debridement, extensive excision of the affected area and early reconstruction.

Key words: osteomyelitis; malignant transformation; Marjolin's ulcer

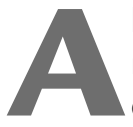

kut enflamatuvar yanıt ve yara iyileşmesi, karmaşık bir dizi biyolojik olayı içeren iyi organize edilmiş bir fizyolojik süreçtir. ${ }^{[1,2]}$ Yüksek enerjili travmayı takiben enfeksiyon gelişimi yumuşak doku problemleri, kemik doku kanlanmasının zayıf olması, hastanın immun yetmezliği ve virulan ve/veya dirençli organizmalar nedeniyle gelişebilir. Bu faktörlerin tümü iyileşmeyi engeller ve potansiyel olarak kronik, tedaviye dirençli bir duruma yol açabilir. ${ }^{[1,3]}$ Kronik osteomiyelit, karmaşık mikrobik kolonilerin ürettiği bir polisakkarit/ protein matriksinde bulunan mikrobiyal ajanların neden olduğu kemik yıkımının eşlik ettiği enflamatuvar bir süreçtir. ${ }^{[4]}$ Oluşan biyofilm tabakası bakterileri konağın bağışıklık sisteminden ve antibiyotiklerin sistemik etkisinden korur ve bu da yerleşik bir enfeksiyonun ortadan kaldırılmasında zorluklara neden olur. ${ }^{[5,6]}$

- İletişim adresi: Uzm. Dr. Çağrı Neyişci, Gülhane Eğitim ve Araştırma Hastanesi, Ortopedi ve Travmatoloji Anabilim Dalı, Ankara Tel: 0530 - 0677610 e-posta: drcagrineyisci@gmail.com

- Geliș tarihi: 8 Haziran $2020 \quad$ Kabul tarihi: 26 Haziran 2020 


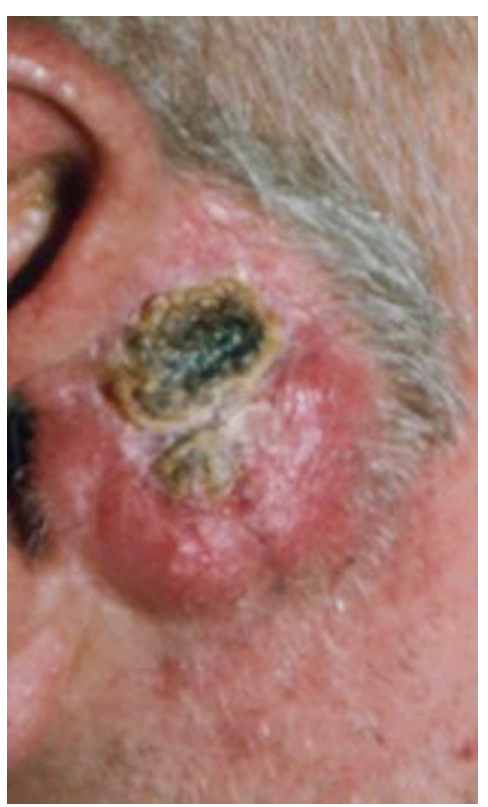

Şekil 1. Marjolin ülserinin klinik görünümü. (Prof. Dr. Erol Koç'un arşivinden)

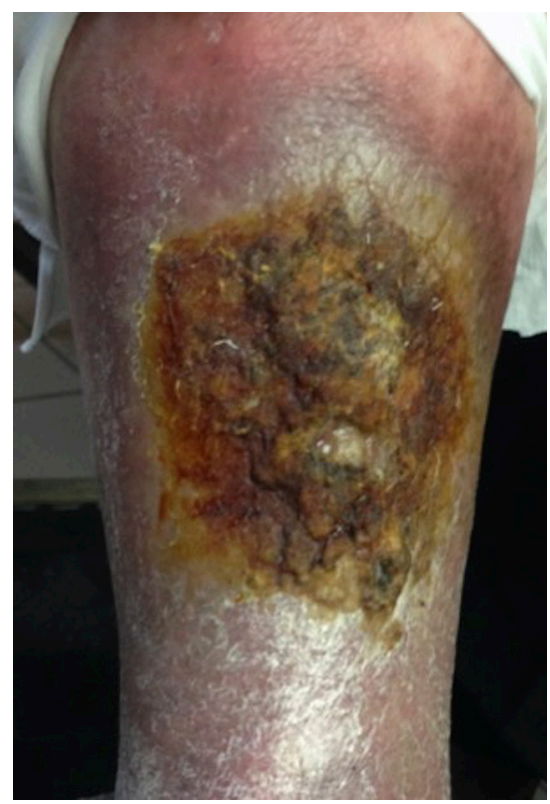

Şekil 2. Skuamöz hücreli karsinomun klinik görünümü. (Prof. Dr. Yusuf Yıldız'ın arşivinden)
Kronik osteomiyeliti olan hastalarla yapılan çalışmalarda, enfeksiyonun karsinogenezisin karmaşık sürecinde teşvik edici bir ajan olarak hareket ettiğini gösteren yüksek düzeyde kanıt bulunmaktadır. ${ }^{[7,8]}$ Kronik osteomiyelit bölgelerinden kaynaklanan malign transformasyonların erken tanı ve agresif yönetimi prognoz ve nihai sonuç için kritik öneme sahiptir. Geniş eksizyon veya ekstremite koruyucu cerrahi planlanamayan hastalarda amputasyon sonrası yumuşak doku ve kemik rekonstrüksiyonu tedavinin temel taşlarını oluşturur. ${ }^{[1,3]}$

Marjolin ülseri (Şekil 1), lezyonun kökenine veya malignite tipine bakılmaksızın, kronik enflamasyon veya cilt yaralanması alanlarından kaynaklanan malign değişimi ifade eder. ${ }^{\left[{ }^{[9]}\right.}$ Kronik yaraların \%1,7'sinde malign dejenerasyonun geliştiği bildirilirken, kronik osteomiyelitli hastaların \%1,6 ila \%23'ünde Marjolin ülserinin oluştuğu rapor edilmiştir. ${ }^{[10-12]}$ Tıbbi tedaviye sınırlı erişimi olan gelişmekte olan ülkelerde, Marjolin ülseri insidansının daha fazla olduğu bilinmektedir. ${ }^{[10,12]}$ Marjolin ülseri en sık 18-40 yaş arası erkeklerde görülür. ${ }^{[7]}$ Osteomiyelitin malign transformasyon süreci 27-30 yıllık bir latent dönem ile 18-72 yıl arasında gerçekleşir. ${ }^{[10,13]}$ Akut olgular da bildirilmiştir ancak nadirdir. ${ }^{[14,15]}$ Kronik osteomiyelitin süresi malign transformasyon için en önemli faktördür. ${ }^{[10]}$ Tibia en sık etkilenen uzun kemiktir, bunu femur ve ayak kemikleri izler; bunun aksine, üst ekstremite kemikleri nadiren etkilenir. ${ }^{[7,13]}$ Paraplejik hastalarda bası yaralarından kaynaklanan osteomiyelit tedaviye dirençlidir ve genellikle hastanın genel durumunda kötüleşmeye katkıda bulunur. ${ }^{[15]}$ Bu hastaların radikal tedavisi ve defektin rekonstrüksiyonu çeşitli zorluklar içermektedir ve yüksek mortalite oranı ile ilişkili olabilir. ${ }^{[14,15]}$ Marjolin ülseri, özellikle bu hasta popülasyonunun ömrünün uzadığı dünyanın gelişmiş bölgelerinde iyi tanımlanmış bir komplikasyondur. ${ }^{[14,15]}$ Marjolin ülserinden büyük bir çoğunlukla agresif skuamöz hücreli karsinom (Şekil 2) gelişir. ${ }^{[7,16,17]}$ Kronik osteomiyelit ile ilişkili diğer maligniteler arasında bazal hücreli karsinom, fibrosarkom, myelom, anjiyosarkom, rabdomiyosarkom, fibroblastik osteosarkom, adenokarsinom, B hücreli lenfoma, plazmasitom, malign fibröz histiyositom, malign hemanjiyoendotelyom ve retikülosarkom bulunmaktadır. ${ }^{[7,16-19]}$

\section{ETYOPATOGENEZ}

Marjolin ülserinin malign dönüşümünün kesin mekanizması belirsizliğini korumaktadır ve tartışmalıdır. ${ }^{[17]}$ Varsayılan temel teori, kronik enflamasyonun kanserojen olduğu şeklindedir. ${ }^{[7,10,11,13,15,17,20-22]}$ Genel olarak, kronik enflamasyon karsinogenezisi, malign transformasyonu, tümör büyümesini, invazyonu ve metastatik yayılmayı destekler. ${ }^{[9,20-22]}$ Kronik enflamatuvar mediyatörler kanser gelişimine pleiotropik etkiler uygularken, enflamatuvar sitokinler potansiyel olarak tümör proteini $p 53$ gibi tümör baskılama genlerinin değişmiş bir ifadesine yol açabilir. ${ }^{[8,9,11]}$ Konakçıya antijen sunumunu azaltan lenfatik obliterasyon ${ }^{[10,17]}$, hücresel mutasyonlara neden olduğu tahmin edilen hasarlı dokulardan salınan toksinler ${ }^{[11,15,17]}$, tümör 
hücrelerinin bağışıklık sisteminin tespitinden kaçabilmesi ile sonuçlanan enfekte dokuların immunolojik hücrelerin tükenmesine neden olduğu immunolojik olaylar serisi etyolojik faktörler arasında bildirilmektedir ${ }^{[10,11,15,17]}$. Ayrıca; yabancı cisim yanıtına neden olabilecek travmatik epitelyal elementlerin implantasyonu[ ${ }^{[11,17]}$, genetik yatkınlık ${ }^{[15,17]}$, enflamasyonun kendi içinde kanserojen olmadığını, önceden var olan neoplastik hücreleri aktive edebileceğini veya bunları diğer kanserojen faktörlere karşı daha duyarlı hale getirebileceğinin iddia eden ko-kanserojen teorisi[15,17] ile ultraviyole ışınlar ${ }^{[17]}$ karsinogenezis için savunulan diğer hipotezlerdir. Büyük olasılıkla, malign transformasyon süreci, karsinogenezise katkısı bulunan çeşitli faktörlere neden olan multifaktöryel bir olaylar sürecidir. ${ }^{[15]}$ Konakta karsinogenezis gelişimine katkıda bulunduğu bildirilen bir başka faktör, bakteriyel enfeksiyonlarda saptanan pan-genom veya supragenomdur. ${ }^{[1]}$

\section{Klinik Özellikler}

Artan ağrı, kötü koku ve artan drenaj, Marjolin ülserlerinin (Şekil 1) en sık görülen semptomlarıdır. ${ }^{[13-16,18]}$ Diğer yaygın klinik bulgular arasında genişleyen veya egzofitik bir kitle, eritem, kanama, tedaviye cevapta azalma veya direnç, lenfadenopati ve hemoraji sayılabilir. ${ }^{[13-16,18]}$ Diğer, daha az sıklıkta ortaya çıkan semptomlar arasında hiperkalsemi, oral alımın azalmasıyla ilişkili kilo kaybı ve hiperpigmente çevre cildi bulunmaktadır. ${ }^{[23,24]}$

\section{Radyoloji}

Malign transformasyon deriden veya fistülün epitelyal yüzünden başlar ve eğer ihmal edilirse kemiğe permeatif şekilde infiltre olur. ${ }^{[13]}$ Hastalığın her aşamasını tespit etmek için çeşitli görüntüleme yöntemleri kullanılır ve bu yöntemler tanıya ulaşmada yardımcı olur. Direkt grafide periosteal değişiklikler ve progresif kemik yıkımı belirgin olmakla birlikte hastalığın daha ileri evrelerinde osteoliz görülmektedir. ${ }^{[13,16,23,25]}$ Kemik iliği invazyonundan sonra, sklerotik hale gelebilir veya tam tersine, medüller yıkım belirginleşebilir. ${ }^{[23-25]}$ Radyografik olarak görülen diğer yaygın bir özellik yumuşak doku kitlesidir. ${ }^{[16,24]}$ Etkilenen bölgenin seri radyografileri, maligniteyi her zaman kanıtlamadığı veya dışlamadığı halde malign transformasyonu düşündüren küçük ayrıntıların tespitinde yararlıdır. ${ }^{[25]}$ Bilgisayarlı tomografi (BT) kemik tutulumunun derecesini en iyi şekilde gösterir ve BT evrelemesi uzak metastazları tespit etmek için özellikle yararlıdır. ${ }^{[16]}$ Manyetik rezonans (MR) görüntüleme yumuşak doku tutulumunu değerlendirebilir. MR'de görülen en sık görünüm yumuşak doku kitleleri ve kemik iliği ödemidir; ancak, bu değişiklikler kronik osteomiyelitte de görülür. ${ }^{[16,26]} \mathrm{MR}$

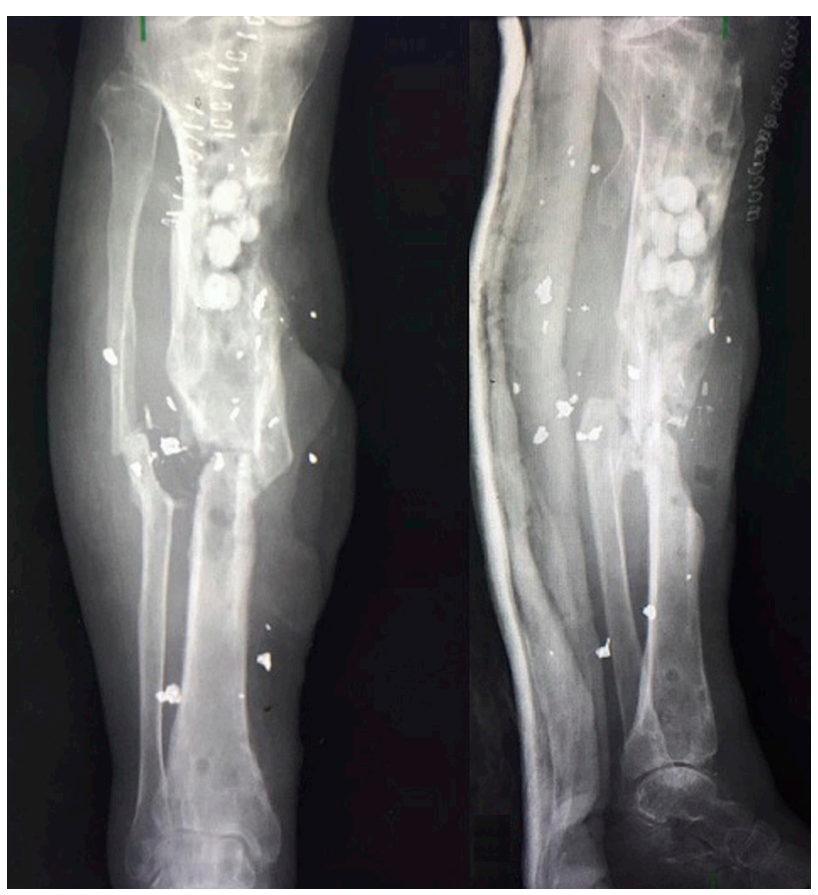

Şekil 3. Tibia'da kronik osteomiyeliti olan hastanın AP/L (anterior posterior ve lateral) radyografisi.

görüntüleme ayrıca skuamöz hücreli karsinomayı diğer yumuşak doku neoplazma tiplerinden ayırt etmek için de kullanılır. ${ }^{[27]}$ Ayrıca MR'nin histolojik bulgularla en iyi şekilde korelasyon kurulan yöntem olduğu bildirilmiştir. ${ }^{[28]}$ Bununla birlikte, görüntüleme yöntemlerinin hiçbirinde malignite belirtisinin görülmediği olgular vardır. Belirtildiği gibi, osteoliz, özellikle hastalığın ilk aşamalarında, tek işaret olabilir; bunun yanında ayrıca, komplike olmamış kronik osteomiyelit (Şekil 3) olgularında da yaygın olarak görülür. ${ }^{[23]} \mathrm{Bu}$ nedenle, malign transformasyonun erken teşhisinde yüksek bir klinik şüphe önem arz etmektedir.

\section{Tanısal Yaklaşım}

Kronik osteomiyelitin gelişim sürecinde görülen bulgularla benzerlik nedeniyle tanı çok zor olabilir. Ayrıntılı bir anamnezin ve kapsamlı bir fizik muayenenin kombinasyonu, hekime değerli bilgiler sağlar. ${ }^{[10]}$ Prensip olarak, kronik osteomiyelit ülserleri/fistülleri (Şekil 4) olan hastaların yakın takip edilmesi gerekir; karakteristik değişiklikler gösteren herhangi bir kronik yara, malign transformasyon şüphesini artırmalıdır. ${ }^{[16,28]}$ Zlowodzki ve ark., altta yatan malignite olmadığından emin olmak için tüm kronik enfeksiyöz veya tümöre benzeyen olguların ilk debridmanı sırasında frozen ve kalıcı patoloji örneklerinin alınması gerektiğini önermektedir. ${ }^{[18]}$ Bir malignitenin tanısal 


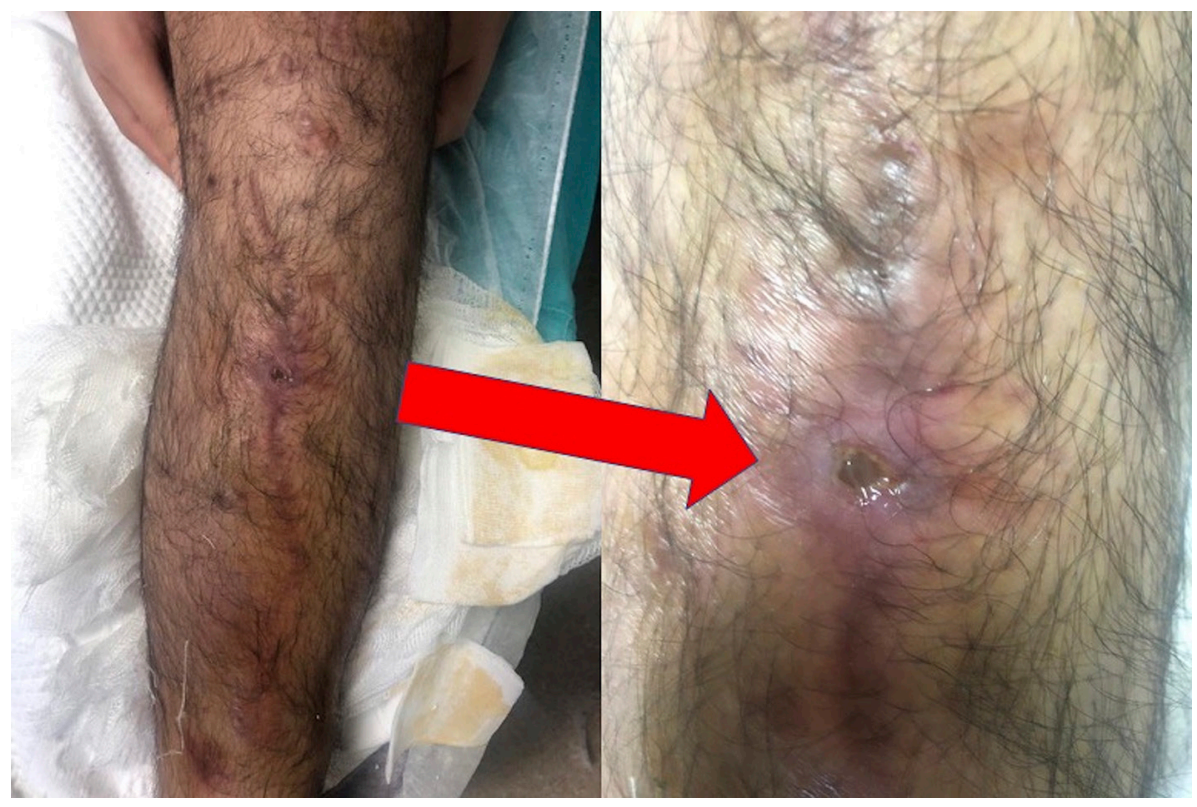

Şekil 4. Tibia'da kronik osteomiyeliti olan hastanın kruris anteriorundaki fistül ağzının klinik görünümü.

doğruluğunu artırmak için farklı alanlardan ve derinliklerden biyopsi alınması ve böylece yanlış negatif sonuçların elde edilmesi riskinin azaltılması ile sağlanabilir. ${ }^{[16,23]}$ Örnekler sinus traktından, ülserden ve kemikten alınan dokuları içermelidir. ${ }^{[10]}$ Bazı yazarlar, kronik osteomiyelit ile ilişkili her yaranın yara tamamen iyileşene kadar iyileşme sürecinde düzenli aralıklarla biyopsilerinin alınması gerektiğini savunmaktadır. ${ }^{[15]}$ Bir biyopsi almak için en uygun zaman tartışmalıdır, ancak çoğu doktor tedavinin başlamasından 3-4 ay sonra ve yaranın standart tedaviye cevap vermediği durumlarda tavsiye etmektedir. ${ }^{[11]}$ Bazı yazarlar da kronik yaraların malign dejenerasyonunun nadir olması nedeniyle, yalnızca şüpheli lezyonlardan biyopsi yapılması gerektiğini öne sürmektedir. ${ }^{[11]} \mathrm{Bir}$ kez malignite tanısı konduktan sonra, BT, MR ve pozitron emisyon tomografisi (PET) gibi ileri radyolojik tetkikler yardımı ile evreleme yapılarak uzak metastazlar ekarte edilebilir. ${ }^{[16,28]}$ Metastaz içeren olgularda BT eşliğinde yapılan biyopsiler kullanılabilir. ${ }^{[24]}$ Lenf nodu biyopsileri de lenfatik yayılımı göstermek için gerekli olabilir; bu, metastaz için en sık tutulum bölgesidir. ${ }^{[15,26]}$ Bununla birlikte, satellit lenf nodlarının mevcudiyeti çoğu zaman enflamatuvar bir reaksiyonu gösterebilir. ${ }^{[13]}$

\section{Ayırıcı Tanı}

Osteomiyelitin özellikleri (litik lezyonlar, kortikal yıkım gibi) diğer bazı tanılarda bildirilen ortak özelliklere benzerlik göstermektedir, bu nedenle ayırıcı tanı daha da zorlaşmaktadır. Erken tanı ve uygun tedavi için ileri değerlendirme ve histopatolojik inceleme çok önemlidir. Skuamöz hücreli karsinomanın ayırıcı tanısında yer alan diğer cilt hastalıkları arasında bazal hücreli karsinom, Bowen hastalığı, kutanöz granülomlar, psoriasis, egzama ve keratoakantomlar bulunur. ${ }^{[27]}$

\section{Prognoz}

Kronik osteomiyelit kaynaklı malign transformasyonun prognozu, temel olarak farkındalık eksikliği ve bu nedenle geç tanı nedeniyle kötüdür. ${ }^{[15]}$ Erken tanı sonrası tam eksizyon sonuçları daha olumludur. ${ }^{[7]}$ Genel olarak, bu maligniteler agresiftir ve özellikle yüksek dereceli lezyonlarda lokal nüks ve lenf nodu metastazı eğilimi mevcuttur. ${ }^{[7]}$ Skuamöz hücreli karsinomlu hastaların \%10-20'sinde lenf nodu metastazının gözlendiği bildirilmiştir. ${ }^{[29]}$ Genel prognoz, lenf nodu metastazı ve uzak metastaz oranı ile belirlenir, metastazların çoğu ilk 18 ay içinde ortaya çıkar. ${ }^{[26,28,29]}$ illk üç yıl boyunca metastatik hastalığı olmayan hastalar genellikle iyi bir prognoza sahiptir. ${ }^{[26]}$ Genel mortalite oranının $\% 9,6$ olduğu bildirilirken, lenfatik yayılım veya uzak metastaz varlığının, sağkalım oranını \%35 ila \%50'ye düşürdüğü rapor edilmektedir.[13]

\section{TEDAVi}

Çoğu klinisyen tarafından önerilen kesin tedavi seçeneği, tümörün proksimalinden amputasyondur. ${ }^{[13,23,27,29]} \mathrm{Bu}$, agresif bir tedavi seçeneği olmasına rağmen, amputasyon hem kronik osteomiyeliti hem de maligniteyi ortadan kaldırmak için nispeten basit 
bir çözüm sunar. Ayrıca, ilerlemiş karmaşık olgularda daha hızlı ve daha güvenli bir kurtarma sağlar. ${ }^{[13]}$ Son zamanlarda, seçilen hastalarda ve uzak metastaz ortaya çıkmadan önce, geniş tam eksizyon önerilmektedir. ${ }^{[11,16]}$ Bir Marjolin ülserinin histolojik tipi skuamöz hücreli karsinom olduğunda, rezeksiyon sınırının net derin bir sınır ile birlikte en az $2 \mathrm{~cm}$ olması gerektiği tavsiye edilmektedir. ${ }^{[29]}$ Uzak metastaz ve lenf nodu tutulumu olmadığında Mohs mikrografik cerrahisinin kullanımı da bildirilmiştir. ${ }^{[11]}$ Bu teknikle, tümör seri kesitlerle mikroskobik olarak takip edilir, böylece tamamen yok edilmesi sağlanır. ${ }^{[11]}$ Geniş rezeksiyonun ardından yumuşak doku defektini kapatmak için serbest doku transferi ve segmental kemik defektini restore etmek için serbest vaskülarize kemik grefti veya distraksiyon osteogenezi yoluyla kemik transferi kullanılabilir. ${ }^{[30]}$ Lezyonun cerrahi eksizyonu mümkün olmadığında amputasyon düşünülmelidir. ${ }^{[10]}$ Parapleji ve sakral/iskial bölgelerde kronik bası yaralarının varlığında, hemipelvektomi ile radikal cerrahi tedavi ve geniş flep rekonstrüksiyonu önerilmektedir. ${ }^{[14,15]}$ Geç tanı ve dolayısıyla kötü prognoz nedeniyle malign transformasyonu önlemek için gerekli müdahalelere olan ihtiyaç vurgulanmaktadır. ${ }^{[14,15]}$

Ek olarak, hasta lenfadenopati ve uzak metastaz açısından taranmalıdır. Bununla birlikte, lenf nodu büyümesinin sıklıkla enflamatuvar nedenlerin bir sonucu olduğu ve tedaviyi takiben düzeldiği için bölgesel lenfadenektomi gerekip gerekmediği tartışmalıdır. ${ }^{[29]}$ Bunun yanında, lenf nodu büyümesi amputasyondan sonra 6-12 hafta devam ederse, cerrahi tedavi gereklidir. ${ }^{[11,29]}$ Adjuvan kemoterapi ve/veya radyoterapi, inoperatif metastatik hastalık ve yüksek dereceli tümörlerin varlığında yararlı olabilir. ${ }^{115,16,23-26]}$ Son olarak, hastanın herhangi bir lokal rekürrens, palpe edilebilen bölgesel lenf nodu veya uzak metastaz bulguları olup olmadığını incelemek için düzenli olarak takibe çağırılması gerekir. ${ }^{[30]}$

\section{SONUÇ}

Kronik osteomiyelitin bir sonucu olarak malign transformasyon nispeten nadir ve geç bir komplikasyondur. Görülme sıklığı daha modern sağlık hizmetleri olan ülkelerde düşüyor gibi görünmekle birlikte, gelişmekte olan ülkelerde bir sorun olmaya devam etmektedir. Bakteriyal enfeksiyon ile malign transformasyon arasındaki süre, çoğu olguda yıllar ve hatta çoğu zaman on yıllar olabilir. Klinik şüphe varlığında vakit kaybetmeden elde edilecek bir yara biyopsisi önem arz etmektedir. En etkili korunma, osteomiyelitin kesin tedavisi, etkilenen alanın yeterli debridmanı ve geniş eksizyonu sonrası modern ekstremite koruyucu ve rekonstrüksiyon yöntemleri kullanılarak erken müdahaledir.

\section{KAYNAKLAR}

1. Panteli M, Puttaswamaiah R, Lowenberg DW, Giannoudis PV. Malignant transformation in chronic osteomyelitis: recognition and principles of management. J Am Acad Orthop Surg 2014;22(9):586-94. Crossref

2. Dargaville TR, Farrugia BL, Broadbent JA, Pace S, Upton Z, Voelcker NH. Sensors and imaging for wound healing: a review. Biosens Bioelectron 2013;41:30-42. Crossref

3. Patzakis MJ, Zalavras CG. Chronic posttraumatic osteomyelitis and infected nonunion of the tibia: current management concepts. J Am Acad Orthop Surg 2005;13(6):417-27. Crossref

4. Lew DP, Waldvogel FA. Osteomyelitis. Lancet 2004;364(9431):369-79. Crossref

5. Forsberg JA, Potter BK, Cierny G III, Webb L. Diagnosis and management of chronic infection. J Am Acad Orthop Surg 2011;19(Suppl 1):S8-19. Crossref

6. Neyisci C, Erdem Y, Bilekli AB, Demiralp B, Kose O, Bek D, Korkusuz F, Kankilic B. Treatment of implant-related methicillin-resistant Staphylococcus aureus osteomyelitis with vancomycin-loaded VK100 silicone cement: An experimental study in rats. J Orthop Surg 2018;26(1):230949901775409. Crossref

7. Samaras V, Rafailidis PI, Mourtzoukou EG, Peppas G, Falagas ME. Chronic bacterial and parasitic infections and cancer: $A$ review. J Infect Dev Ctries 2010;4(5):267-81. Crossref

8. Sell S. Infection, stem cells and cancer signals. Curr Pharm Biotechnol 2011;12(2):182-8. Crossref

9. Multhoff $\mathrm{G}$, Molls M, Radons J. Chronic inflammation in cancer development. Front Immunol 2011;2:98. Crossref

10. Kerr-Valentic MA, Samimi K, Rohlen BH, Agarwal JP, Rockwell WB. Marjolin's ulcer: Modern analysis of an ancient problem. Plast Reconstr Surg 2009;123(1):184-91. Crossref

11. Trent JT, Kirsner RS. Wounds and malignancy. Adv Skin Wound Care 2003;16(1):31-4. Crossref

12. Onah II, Olaitan PB, Ogbonnaya IS, Onuigbo WI. Marjolin's ulcer (correction of ucler) at a Nigerian hospital (19932003). J Plast Reconstr Aesthet Surg 2006;59(5):565-6. Crossref

13. Alami M, Mahfoud M, El Bardouni A, Berrada MS, El Yaacoubi M. Squamous cell carcinoma arising from chronic osteomyelitis. Acta Orthop Traumatol Turc 2011;45(3):1448. Crossref

14. Lack W, McKinley T. Marjolin's ulcer: Incidental diagnosis of squamous cell carcinoma on hemipelvectomy for recalcitrant pelvic osteomyelitis. lowa Orthop J 2010;30:174-6. https:// www.ncbi.nlm.nih.gov/pmc/articles/PMC2958291/

15. Fairbairn NG, Hamilton SA. Management of Marjolin's ulcer in a chronic pressure sore secondary to paraplegia: A radical surgical solution. Int Wound J 2011;8(5):533-6. Crossref

16. Ogawa B, Chen M, Margolis J, Schiller FJ, Schnall SB. Marjolin's ulcer arising at the elbow: A case report and literature review. Hand (NY) 2006;1(2):89-93. Crossref

17. Chalya PL, Mabula JB, Rambau P, Mchembe MD, Kahima KJ, Chandika AB, Giiti G, Masalu N, Ssentongo R, Gilyoma JM. Marjolin's ulcers at a university teaching hospital in Northwestern Tanzania: A retrospective review of 56 cases. World J Surg Oncol 2012;10(1):38. Crossref

18. Zlowodzki M, Allen B, Schreibman KL, Vance RB, Kregor PJ. Malignant fibrous histiocytoma of bone arising in chronic osteomyelitis. Clin Orthop Relat Res 2005;(439):269-73. Crossref 
19. Smith J, Mello LF, Nogueira Neto NC, Meohas W, Pinto LW, Campos VA, Barcellos MG, Fiod NJ, Rezende JFN, Cabral CEL. Malignancy in chronic ulcers and scars of the leg (Marjolin's ulcer): A study of 21 patients. Skeletal Radiol 2001;30(6):331-7. Crossref

20. Coussens LM, Werb Z. Inflammation and cancer. Nature 2002;420(6917):860-7. Crossref

21. Kenny PA, Nelson CM, Bissell MJ. The ecology of tumors: By perturbing the microenvironment, wounds and infection may be key to tumor development. Scientist 2006;20(4):30. https://www.ncbi.nlm.nih.gov/pmc/articles/PMC2995893/

22. Bissell MJ, Kenny PA, Radisky DC. Microenvironmental regulators of tissue structure and function also regulate tumor induction and progression: The role of extracellular matrix and its degrading enzymes. Cold Spring Harb Symp Quant Biol 2005;70:343-56. Crossref

23. Pandey M, Kumar P, Khanna AK. Marjolin's ulcer associated with chronic osteomyelitis. J Wound Care 2009;18(12):5046. Crossref

24. Hall AB, Buehler KE, Philipneri M. Hypercalcemia complicating Marjolin's ulcer. Mil Med 2009;174(3):308-10. Crossref
25. Puri A, Parasnis AS, Udupa KV, Duggal A, Agarwal MG. Fibroblastic osteosarcoma arising in chronic osteomyelitis. Clin Radiol 2003;58(2):170-2. Crossref

26. Rauh MA, Duquin TR, McGrath BE, Mindell ER. Spread of squamous cell carcinoma from the thumb to the small finger via the flexor tendon sheaths. J Hand Surg Am 2009;34(9):1709-13. Crossref

27. Kersh S, Lakhani S, Ramanujam CL, Derk F, Zgonis T. Concomitant acute osteomyelitis and squamous cell carcinoma of the foot: A case report. Clin Podiatr Med Surg 2010;27(4):635-41. Crossref

28. Wolf H, Platzer $P$, Vécsei $V$. Verrucous carcinoma of the tibia arising after chronic osteomyelitis: A case report. Wien Klin Wochenschr 2009;121(1-2):53-6. Crossref

29. Altay M, Arikan M, Yildiz Y, Saglik Y. Squamous cell carcinoma arising in chronic osteomyelitis in foot and ankle. Foot Ankle Int 2004;25(11):805-9. Crossref

30. Hwang KT, Youn S, Kim JT, Lee SH, Ng SW, Kim YH. Use of latissimus dorsi flap pedicle as a T-junction to facilitate simultaneous free fibular flap inset in lower extremity salvage. J Plast Reconstr Aesthet Surg 2012;65(4):517-20. Crossref 